\section{Flu gene discovery prompts calls for tighter monitoring}

\section{Erika Check}

Genes from a flu strain created in a lab in $\mathbf{1 9 4 0}$ have been found in samples taken from pigs in South Korea, a US biologist claims.

Data from the flu virus samples were put last October in GenBank, the public database of genetic sequence information, by researchers at Chungnam National University in Daejon, South Korea.

In December, the biologist Henry Niman of Recombinomics, a biotechnology company in Pittsburgh, Pennsylvania, examined the data as part of an analysis of flu sequences. $\mathrm{He}$ concluded that the samples contained genes from a strain of human flu virus that was created decades ago by scientists experimenting with the virus that caused the global flu pandemic of 1918 .

Neither the World Health

Organization (WHO), which coordinates the international response to flu, nor the South Korean government have commented on the claim. But Laurie Garrett, a former journalist and analyst at the Council on Foreign Relations in New York, says that the WHO attributes the sequence to an error at the lab that deposited the information.

Sang Heui Seo, one of the Korean researchers, says he is unable to comment yet, adding that "further confirmation" of the sequence "is under way at this moment".

The incident raises worrying questions about how the human flu genes got into a virus in a pig, says Niman. It could have happened naturally or in a lab accident but it could also have resulted from experiments to produce a more deadly flu. "It could be bioterrorism," he says.

Niman says that the flu sequences posted on GenBank contain genes from a human strain called WSN/33, which was created in 1940 in a London lab. The strain was derived from a 1933 virus related to the one that caused the 1918 pandemic, and most people's immune systems have never been exposed to anything like it. The strain could be devastating if it infected people today, he adds.

Garrett thinks that even if there was a lab error, the episode should still ring alarm bells. Without a robust, global disease-surveillance network, she says, it is impossible to confirm the WHO's view that the sequence is a mistake. The discovery of the mystery strain "reveals critical weaknesses in our global security system", she contends.

\title{
New York draws fire over case of drug-resistant HIV
}

Erika Check, Washington

A decision by New York health officials to announce the detection of an unusually aggressive case of AIDS has led to criticism from some researchers and activists.

In December last year, a man from New York City tested positive for HIV and quickly showed signs of AIDS. Doctors at New York's Department of Health and Mental Hygiene believe that he developed AIDS between 2 and 20 months after he was infected; the disease usually takes about a decade to develop.

The patient's virus also resists treatment by the three important classes of HIV-fighting drugs. Officials at the health department say that this multiple drug resistance and the rapid progression to AIDS led them to warn the public of the possible spread of the strain. "This case is a wake-up call," the city's health commissioner Thomas Frieden told a press conference on 11 February.

Some scientists and doctors have praised the decision to publicize the case. They hope that it will warn the public about the dangers of having sex while under the influence of the drug crystal methamphetamine, or crystal meth. The infected patient had unprotected sex with many men while using the drug. "My hope is that this news will bring the reality to the public, and we will see less risky behaviour," says Jay Levy, a virologist at the University of California, San Francisco.

But others questioned whether the information released about the virus justified the public announcement. Similar cases have been reported before, critics say, but have not led to epidemics. In 2003, for example, researchers in British Columbia, Canada, reported two cases of HIV that seem similar to the New York virus. The Canadian patients were also infected with multidrug-resistant HIV that rapidly progressed to AIDS (K. C. W. Chan et al. AIDS 17, 1256-1258; 2003). But these viruses did not cause a widespread epidemic of HIV'superstrains'.

"I don't think the health department needed to hang its public-health campaign on a single anecdotal virus," says John Moore, a virologist at Weill Medical College at Cornell University in Ithaca, New York.

The virus is being studied by researchers at the Aaron Diamond AIDS Research Center at Rockefeller University in New York. More data on the strain are scheduled to be released at the 12th Conference on Retroviruses and Opportunistic Infections in Boston this week.

But the Aaron Diamond's involvement has also drawn criticism. Some have even suggested that the centre pushed for the announcement to build interest in the retro-

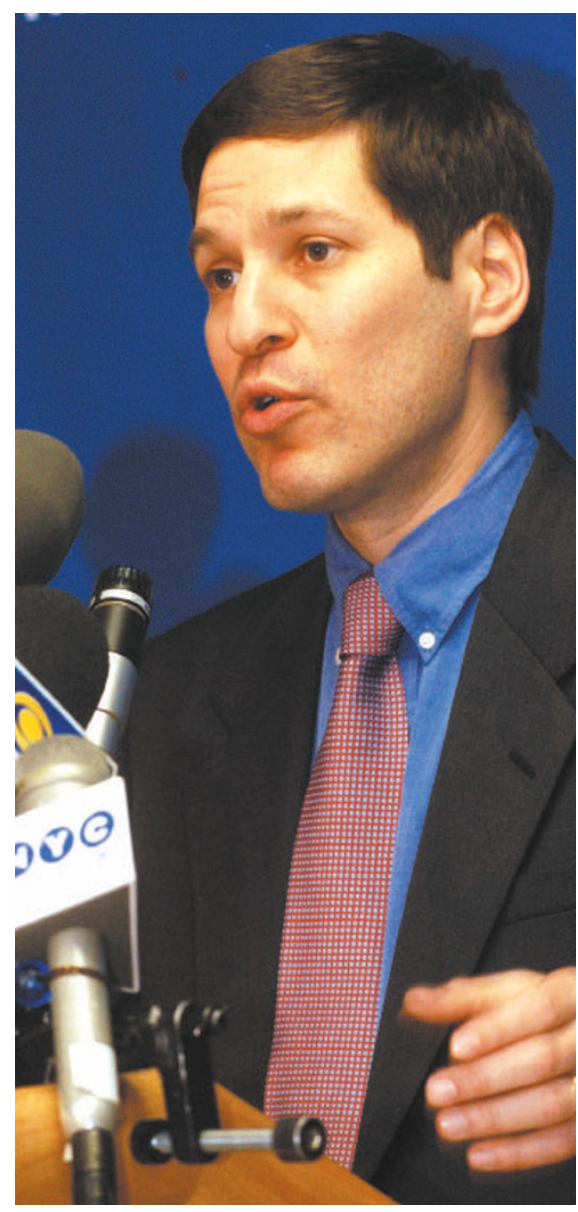

Thomas Frieden is facing criticism for revealing the discovery of a virulent case of HIV.

virus conference, whose programme committee is chaired by David Ho, the Aaron Diamond's scientific director.

"There's a lot of suspicion because there's a confluence of issues, including the fact that the conference is around the corner, and David Ho is its chair," says Richard Jefferys, basic-science project director at the New York-based Treatment Action Group.

But Ho says that the health department made the call to alert the public about the virus after consulting with the US Centers for Disease Control and Prevention in Atlanta, Georgia. Ho adds that his group is presenting its data in the first available scientifically appropriate forum - the retrovirus conference. "I'm saddened by people who are trying to turn this into a personal attack rather than keeping focused on the case and its publichealth ramifications," Ho says.

The health department also defended its action. "We had the necessary information and we were confident - and remain confident - that the situation was of great publichealth significance," says an official. 